\title{
Process Parameters for Chironji Nut (Buchanania lanzan.) Decortication
}

\author{
M.M. Dange ${ }^{1 *}$, P.S. Champawat ${ }^{1}$, P.H. Bakane ${ }^{2}$, S.D. Deshmukh ${ }^{2}$, \\ S.K. Jain ${ }^{1}$ and P.A. Borkar ${ }^{2}$ \\ ${ }^{1}$ Department of Processing and Food Engineering, CTAE, M.P.U.A.T., \\ Udaipur-313001, Rajasthan, India \\ ${ }^{2}$ Department of Agriculture Process Engineering, Dr. PDKV, Akola-444001, M.S., India \\ *Corresponding author
}

\begin{tabular}{|c|}
\hline Keywords \\
\hline $\begin{array}{l}\text { Chironji nut, } \\
\text { Decortication } \\
\text { efficiency, Whole } \\
\text { kernel recovery, } \\
\text { Capacity of } \\
\text { machine, Response } \\
\text { surface } \\
\text { methodology }\end{array}$ \\
\hline Article Info \\
\hline $\begin{array}{l}\text { Accepted: } \\
12 \text { December } 2018 \\
\text { Available Online: } \\
10 \text { January } 2019\end{array}$ \\
\hline
\end{tabular}

\section{A B S T R A C T}

Buchanania lanzan (Chironji) a member of family Anacardiaceae consist of a hard nut that on decortication yields kernel containing $52 \%$ of oil and this oil is used as a substitute for olive and almond oil. Also, kernel is used for sweet meals, medicinal purpose, cosmetics etc. By manual decortication the capacity was observed to be minimum and recovery of whole kernel was nearly $12 \%$ only. This manual method is time consuming, laborious, inefficient and there is fear of injury to fingers. Decortication of chironji nut is a major problem and hence this valuable chironji kernel is to be procured at high price i.e. Approx. Rs.700-1000, whereas the chironji nut could be purchased at the rate of Rs. 100 to $150 / \mathrm{kg}$. As the kernel is valuable, it was necessary to get maximum recovery during decortication so as to reduce the cost. Thus, considering all the facts related to the valuable kernel, decortication followed by drying of nut has been studied in detailed to obtain maximum recovery of good quality kernels. The RSM technology is applied for optimization of process parameters. Optimization of process parameters using response surface methodology (RSM) greatly overcomes the numbers of experimental trials generally undertaken for decorticating study of chironji nuts apart from maximizing the output of the system. The independent parameters for chironji nut decortication viz., drying temperature, drying time and clearance between discs were optimized using RSM. The drying temperature of $69.610^{\circ} \mathrm{C}$, drying time $163.87 \mathrm{~min}$ and clearance between disc $12 \mathrm{~mm}$ were found optimal. The whole kernel recovery, decorticating efficiency, unshelled nut, broken kernel and capacity of machine at optimized independent parameters were $27.72 \%$ (fraction of chironji kernel to shell $30.01 \%$ to $69.99 \%$ ), $85.299 \%, 11.50 \%, 3.687$ $\%$ and $6.232 \mathrm{~kg} / \mathrm{h}$ respectively. The investigation is most useful to the small farmers, small entrepreneurs, Self-help group, Organic farming groups, Tribal group, A rural youth, Ladies bachat group who are involved in decortication of chironii nut.

\section{Introduction}

The level of agricultural products goes on increasing with mechanization of different post-harvest operations, which aims at achieving timeliness of operations, efficient use of inputs, improvement in quality of produce, safety and comfort of labours, reduction in loss of produces and drudgery of labours. 
Buchanania lanzan commonly known as 'Charoli' or 'Chironji', Chawar, Achar, Cuddapah almond, Piyal etc. is a valuable species belonging to family Anacardiaceae. Chironji is not cultivated as regular plantation. It is found growing as stray plantation in natural habitat. Exact statistics as regard to area is not available. However, density of population across various forest range, gives an idea as regard to plant stand and the production. The yield of chironji is from 1 to $5 \mathrm{~kg}$ / tree with an average weight of 0.27 g (Chandhar, 1997; Rai, Y.C, 1982). According to market information system non timber forest product, the annual national production of chironji is 97,500 quintal/year.

Chironji has great medicinal value. All the parts of the chironji tree are used in traditional Indian medicine. Kernel is rich in protein content (20-30\%). The oil extracted from kernels is used for treating skin diseases and it is considered as a substitute for almond oil in traditional medicinal preparations. The chironji nut has very good demand in India as well as in foreign markets and thus, has become an important crop. Therefore, to earn foreign exchange the government and private agencies have evinced keen interest in developing this industry, both by increasing its production and processing capacity.

At times in order to get more benefit from the existing machinery/mechanism with a slight modification or slight change can make the machine versatile. At present shelling of Chironji nut is done manually and sometime by traditional grinder which is time consuming operation. Traditional method of decortication i.e. manual decortication is shown in Plate 1.1.

It was observed that the expertise male labour was able to crack/shell $85 \mathrm{~g} / \mathrm{h}$ of chironji nut with the help of two flat stone. Also, the quality of the kernel depends upon an efficient nut decorticating which helps to enhancing effective separation of the kernel from shell. It was observed that manual method is time consuming, laborious, inefficient and also there is fear of injury to fingers. Therefore, it becomes difficult to get labour for this operation. Decortication is the most important operation of post-harvest handling of nuts. Only a research work was carried out on Chironji nut by Kumar et. al in 2009 , for decortication of chironji nut, where they used horizontal disc for shelling of chironji nuts. At present, loss of about 15-17 $\%$ (as broken kernel) due to improper shelling practices, uncontrolled operational parameters, and lack of knowledge about decortication. Such factor has made agriculture products less profitable and more risky. Keeping the above point in view the present investigation was undertaken with objective to optimize the process parameters for chironji nut decortication by using RSM technology. Some work has been done in identification of emery grade and few for milling studies (Sahay et.al., 1988; Mungraj et.al., 2005). Other researchers have worked on the optimization of process parameter for milling of various pulses. Response surface methodology has been successfully employed for the optimization of pulse milling operation Therefore, the machine and process parameters of existing burr mill at AICRP on PHET. Dr. PDKV Akola was optimized using response surface methodology for decortication of chironji nuts.

\section{Materials and Methods}

Raw Material Chironji nuts (Buchanania Lanzan) with moisture content 7-8 (\% db) were obtained from farmers of Patur Tehsil of Akola district.

\section{Manual decortication of chironji nuts}

The chironji nuts having moisture content of $7.01(\% \mathrm{db})$ was used for manual 
decortication. A labour carried out the decortication process using two stone slabs. One slab was used for resting the nut and the other was used for breaking/cracking the chironji nut. The total time required by the labour to decorticate $200 \mathrm{~g}$ sample of chironji nut was nearly $3 \mathrm{~h}$. During this process each nut was decorticated and the various fractions of nut were obtained as given below

\begin{tabular}{|l|l|}
\hline Variables & $\begin{array}{l}\text { Manual } \\
\text { decortication }\end{array}$ \\
\hline $\begin{array}{l}\text { Decortication efficiency } \\
\text { (\%). }\end{array}$ & 100 \\
\hline Unshelled nut (\%). & 0 \\
\hline Whole kernel (\%). & 12.375 \\
\hline Broken kernel (\%). & 17.629 \\
\hline $\begin{array}{l}\text { Capacity of decortication } \\
\text { (kg/h). }\end{array}$ & 0.066 \\
\hline
\end{tabular}

Decortication of chironji nuts with existing burr mill/chironji nut decorticator along with drying

Machine: The existing burr mill (Plate 2) at AICRP on PHET, Dr. PDKV Akola with overall dimensions of $600 \times 290 \times 25 \mathrm{~mm}$, power unit $1 \mathrm{hp}$ electric motor, labour requirement one (to operate machine) was used for all the decorticating studies. It consists of a feed hopper, inlet chute, adjustable nob, outlet casing, delivery chute, emery disc, motor, shaft, pulley and frame. The emery disc rotated inside the casing. Decortication took place due to friction between nuts and abrasive surface.

Method: The decorticating method was used for the study with details are given in Figure 1 .

\section{Design of experiment}

The Box- Behnken design of three variables and three levels including 17 trials formed by 5 central points was used with three independent process parameters viz., drying temperature $(\mathrm{T})$, drying time $(\mathrm{t})$ and clearance between discs (C) was considered for optimization. Experimental plan for optimization constituted five responses viz., whole kernel recovery (\%), decortication efficiency $(\%)$, capacity of machine $(\mathrm{kg} / \mathrm{h})$, broken kernel (\%) and unshelled nut (\%). For this purpose, response surface methodology (RSM) was employed to fit a second-order polynomial equation for decorticating chironji nut. Value of $\mathrm{T}$ varies from 50 to $70^{\circ} \mathrm{C}$, $\mathrm{t}$ between 120 and $240 \mathrm{~min}$, and $\mathrm{C}$ between 8 to $12 \mathrm{~mm}$. The process parameters were optimized for maximizing the decortication efficiency, whole kernel recovery and capacity of machine using the package, Design- Expert version 9.0.5.1 (Stat Ease Inc, Minneapolis, MA Trial version, 2015).

Second order polynomial equation of the following form was assumed to relate the response, $\mathrm{Y}_{\mathrm{k}}$ and the factors, as

$$
Y_{k}=\beta_{k o}+\sum_{i=1}^{i=3} \beta_{k i} x_{i}+\sum_{i=1}^{i=3} \beta_{k i i} x_{i}^{2}+\sum_{i=1}^{i=2} \sum_{j=i+1}^{j=3} \beta_{k j} x_{i} x_{j}
$$

Where, $Y_{k}$ is response (i.e. decortication efficiency, un-shelled nut, whole kernel recovery, broken kernel and Capacity of machine) $\beta_{\mathrm{ko}}, \beta_{\mathrm{ki}}, \beta_{\mathrm{kii}}$ and $\beta_{\mathrm{kij}}$ are constant coefficients and $x_{i}$ and $x_{j}$ are the coded independent variables that are linearly related to $X_{1}, X_{2}$ and $X_{3}$. A total number of 17 experiments were carried out as evident from Table 1. The experiments were conducted in random order. Five repeated experiments were conducted at the central points of the coded variables to calculate the error sum of squares and the lack of fit of the developed regression equation between the responses and independent variables (Mayers et al., 2002).

The experiments were conducted and samples of decorticated product were taken for determination of whole kernel recovery, decorticating efficiency, capacity of machine 
(kg/h), unshelled nut and broken kernel. This was calculated as per the following formula

1. Decortication efficiency $(\%)$ :

Decortication efficiency $(\%)=100-$ uncracked nuts (\% unshelled)

2. Un-cracked/unshelled nuts (\%):

Un-cracked nuts $=\mathrm{C} / \mathrm{D} \times 100$

Where,

$\mathrm{C}=$ Weight of un-cracked nuts, $\mathrm{g}$.

$\mathrm{D}=$ Weight of total nuts, $\mathrm{g}$.

3. Whole kernel (\%):

Whole kernel $(\%)=\mathrm{G} / \mathrm{D} \times 100$

Where,

$\mathrm{G}=$ Weight of whole kernels, $\mathrm{g}$.

4. Broken kernels (\%):

Broken kernels $(\%)=\mathrm{E} / \mathrm{D} \times 100$

Where,

$\mathrm{E}=$ Weight of split kernels, $\mathrm{g}$.

5. Output/ capacity of machine:

Output/ capacity of machine $=\mathrm{W} / \mathrm{T}$

Where,

$\mathrm{W}=$ Weight of chironji nut, $\mathrm{kg}$.

$\mathrm{T}=$ Time required for decortication, $\mathrm{h}$.

\section{Results and Discussion}

Response surface analysis was applied to the experimental data (Table 1), and the secondorder polynomial response surface model (Eq. 1) was fitted to each of the response variables. Regression analysis and analysis of variance (ANOVA) were conducted for fitting the model and to examine the statistical significance of the model terms. The estimated regression coefficients of the quadratic polynomial models for the response variables, along with the corresponding $\mathrm{R}^{2}$ and coefficient of variation $(\mathrm{CV})$ values, are given in Table 2. Analysis of variance showed that all the models were significant $(\mathrm{p}<0.01$ and $\mathrm{p}<0.05$ ) for all the responses (Table 2). The lack of fit (Table 2), which measures the fitness of the model, did not result in a significant $F$ value for whole kernel recovery, decorticating efficiencies, capacity of machine, unshelled nut and broken kernel indicating that these models are sufficiently accurate for predicting those responses.

\section{Whole kernel recovery}

The effect of clearance between pair of disc, drying temperature and drying time on whole kernel recovery was determined by keeping one variable constant with respect to others shown in Figure 2. It could be evident that percentage of whole kernel increase with increase in clearance between pair of discs as well as with increase in drying temperature. This both parameters had shown a highly significant effect on whole kernel recovery. It also confirms the findings that percent whole kernels first increases with drying time and then slight decreases. Clearance between pair of disc was showing significant difference as compared to drying temperature and drying time. This may be due to the fact that chironji nut is having varying size.

The equation in terms of actual factors which described the effect on whole kernel is given as

Whole kernel $=\quad-7.76292+$ $0.066625 * \mathrm{~T}+0.12546 * \mathrm{t}+1.59688 * \mathrm{C}-$ $3.37731 \mathrm{E}-004 * \mathrm{t}^{2}$

\section{Decortication efficiency}

The decortication efficiency was observed to be ranging from 70.12 to $86.34 \%$ depending upon various treatments. The minimum decortication efficiency was found for treatment having the combination of drying temperature $50{ }^{\circ} \mathrm{C}, 180 \mathrm{~min}$. drying time and 8 $\mathrm{mm}$ clearance between pair of disc. The maximum decortication efficiency was observed in case of treatment having the combination drying temperature of $70^{\circ} \mathrm{C}, 180$ min drying time and $12 \mathrm{~mm}$ clearance between pair of disc. It was observed that clearance between pair of disc was showing 
significant difference as compared to drying time and drying temperature (Fig. 3). It revealed that decortication efficiency increased with increase in clearance between discs and shows slight increase with the increasing drying time. The drying temperature helps to make the chironji nut brittle. Cracking of nut becomes easy when it is fed to the burr mill thus giving maximum decortication efficiency.The regression equation describing the effect of process variables on decortication efficiency are given as

$\begin{array}{lll}\text { Decortication } & \text { efficiency }= & \text { - } \\ 35.99667+0.18200 * & \mathrm{~T}+18.74556 * & \mathrm{C}- \\ 0.80778 * \mathrm{C}^{2} & \ldots(2)\end{array}$

\section{Unshelled Nut}

The minimum unshelled nut were found for treatment having the combination of drying temperature $70{ }^{\circ} \mathrm{C}$, drying time $180 \mathrm{~min}$ and clearance between pair of disc $12 \mathrm{~mm}$. The maximum unshelled nut were observed in case of treatment having the combination of drying temperature $50^{\circ} \mathrm{C}$, drying time $180 \mathrm{~min}$ and clearance between pair of disc $8 \mathrm{~mm}$.

Effect of independent variables on unshelled nut shows (Fig. 4) that percentage of unshelled nut decreases with increase in clearance between discs and slight decrease with increase in drying temperature. It was observed that there is no significant effect of drying time on percent unshelled nut.

The response surface equation was obtained for the model of second degree is as under.

Un-shelled nuts $=+62.23167-0.075625^{*} \mathrm{~T}$ $7.25681 * \mathrm{C}+0.28903 * \mathrm{C}^{2}$

\section{Broken kernel}

The broken kernel was observed to be ranging from 3.03 to $10.24 \%$ depending upon various treatments. The minimum broken kernel were found for treatment having the combination of drying temperature $60{ }^{\circ} \mathrm{C}$, drying time 120 min. and clearance between pair of disc 12 $\mathrm{mm}$. The maximum broken kernel was observed in case of treatment having the combination of drying temperature $50^{\circ} \mathrm{C}$, drying time $180 \mathrm{~min}$. and clearance between pair of disc $8 \mathrm{~mm}$. The broken kernels decrease with increase in clearance between disc and shown slight decrease with the increasing drying temperature (Fig. 5). The response of broken kernel was observed to be significant with independent parameters viz. clearance between disc and drying temperature.

The response surface equation was obtained for the model of second degree in terms of actual factors is given as,

$\begin{array}{lll}\text { Broken } \quad \text { kernel }= & +5.47-0.26 * \mathrm{~T}- \\ 3.02 * \mathrm{C}+0.56 * \mathrm{TC}+0.95 * \mathrm{C}^{2} & \ldots(4)\end{array}$

\section{Capacity of machine}

The capacity of machine was observed to be ranging from 3.8 to $6.69 \%$ depending upon various parameters. The minimum machine capacity was found for treatment having the combination of drying temperature $50^{\circ} \mathrm{C}$, drying time $180 \mathrm{~min}$. and clearance between pair of disc $8 \mathrm{~mm}$. The maximum machine capacity was observed in case of treatment having the combination of drying temperature $60^{\circ} \mathrm{C}$, drying time $120 \mathrm{~min}$ and clearance between pair of disc $12 \mathrm{~mm}$. Capacity of machine increases with increase in clearance between discs. Again, it was observed that capacity of machine increased with increase in drying temperature (Fig. 6). This both parameters had shown a significant effect on capacity of machines.

The equation in terms of actual factors which described the effect on capacity of machine is given as, 
Capacity of Machine = 23.08053+0.51380*T-3.97917E$003 * t+2.22668 * \mathrm{C}-$ $0.087303 * \mathrm{C}^{2}$ $4.11711 \mathrm{E}-003 * \mathrm{~T}^{2} \quad-$

Optimization of process parameters for appropriate decortication of chironji nuts

The whole kernel recovery (\%), decorticating efficiency $(\%)$, unshelled nut (\%), broken kernel $(\%)$ and capacity of machine $(\mathrm{kg} / \mathrm{h})$ were taken as responses in order to optimize the machine parameters. The optimization was carried out using response surface methodology (Design Expert 9.0.5.1). The optimized values of drying temperature, drying time and clearance between pair of disc were taken for further study. Numerical (Table 3) and graphical optimizations (Fig. 7) were carried out for obtaining the appropriate design parameter for obtaining optimum whole kernel recovery (\%), decorticating efficiency (\%), unshelled nut (\%), broken kernel $(\%)$ and capacity of machine $(\mathrm{kg} / \mathrm{h})$. Design expert program of the STATEASE software was utilized (Design Expert 9.0.5.1) for simultaneous optimization of the multiple

Plate.1 Manual Decortication of chironji nut

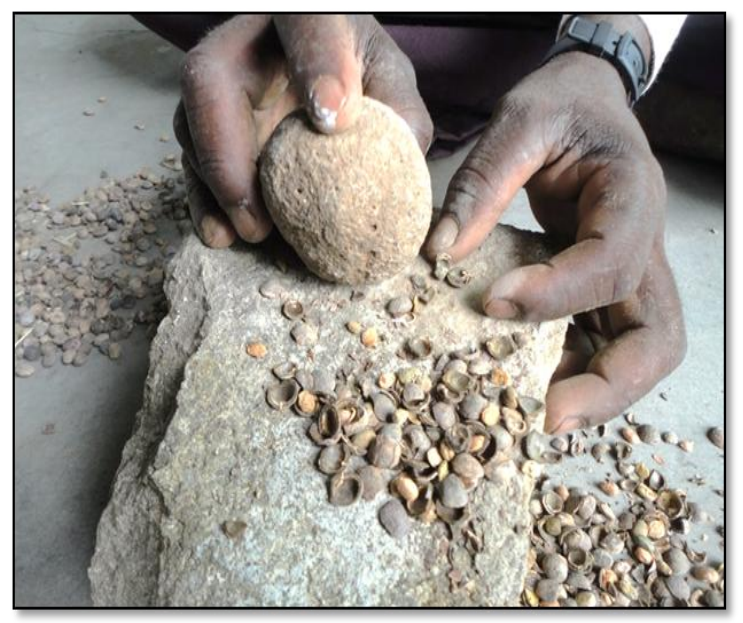

regressions, and responses were chosen and different weights assigned to each goal to adjust the shape of its particular desirability function.

The drying temperature of $69.610{ }^{\circ} \mathrm{C}$, drying time $163.87 \mathrm{~min}$ and clearance between disc $12.00 \mathrm{~mm}$ for the chironji nut decorticator were found optimal for the decortication of chironji nut. At this optimized condition, the whole kernel recovery, decorticating efficiency, unshelled nut, broken kernel and capacity of machine were $27.527 \%, 85.299$ $\%, \quad 11.50 \%, 3.687 \%$ and $6.232 \mathrm{~kg} / \mathrm{h}$ respectively (Table 2). The decortication experiment results were in close agreement with the response variable values at optimized independent parameters. The findings of the optimization study, viz., whole kernel recovery (\%), decorticating efficiency (\%), unshelled nut (\%), broken kernel $(\%)$ and capacity of machine $(\mathrm{kg} / \mathrm{h})$ and developed models were compared with the manual decortication of chironji nut. The manual decortication capacity was observed to be $0.066 \mathrm{~kg} / \mathrm{h}$ whereas burr mill /chironji nut decorticator was having a capacity of $6 \mathrm{~kg} / \mathrm{h}$.

Plate.2.Chironji nut decorticator

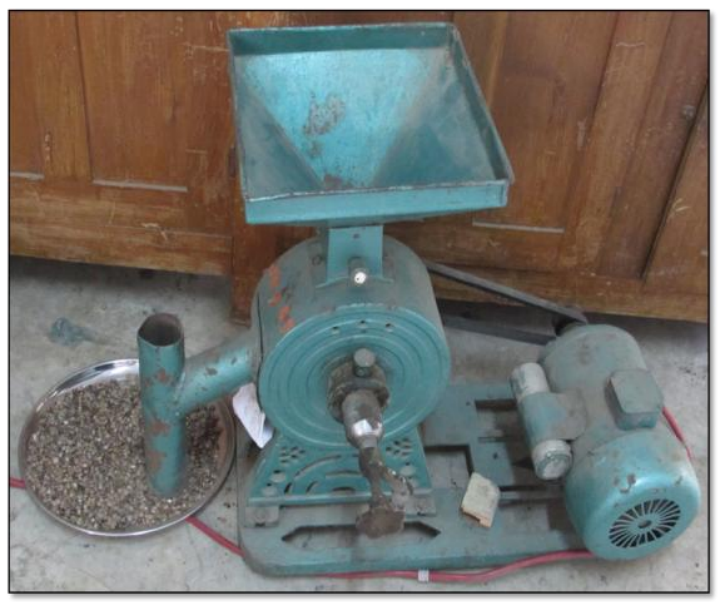


Table.1 Effect of independent variables on response parameters

\begin{tabular}{|l|l|l|l|l|l|l|l|l|}
\hline $\begin{array}{l}\text { Sr. } \\
\text { no. }\end{array}$ & $\begin{array}{l}\text { Drying } \\
\text { temperature } \\
\left({ }^{\circ} \mathbf{C}\right)\end{array}$ & $\begin{array}{l}\text { Dryin } \\
\text { g time } \\
\text { (min) }\end{array}$ & $\begin{array}{l}\text { Clearance } \\
\text { between } \\
\text { pair } \\
\text { disc(mm) }\end{array}$ & $\begin{array}{l}\text { De- } \\
\text { hulling } \\
\text { Efficiency }\end{array}$ & $\begin{array}{l}\text { Un- } \\
\text { shelled } \\
\text { Nuts }\end{array}$ & $\begin{array}{l}\text { Whole } \\
\text { kernel }\end{array}$ & $\begin{array}{l}\text { Broken } \\
\text { Kernel }\end{array}$ & $\begin{array}{l}\text { Capacity } \\
\text { of } \\
\text { Machine }\end{array}$ \\
\hline & $\mathbf{T}$ & $\mathbf{t}$ & $\mathbf{C}$ & \% & \% & \% & \% & kg/h \\
\hline $\mathbf{1}$ & 60 & 180 & 10 & 79.39 & 13.33 & 23.32 & 6.08 & 5.18 \\
\hline $\mathbf{2}$ & 60 & 240 & 8 & 74.78 & 17.79 & 20.79 & 9.72 & 4 \\
\hline $\mathbf{3}$ & 60 & 120 & 12 & 80.68 & 12.43 & 25.97 & 3.03 & 6.69 \\
\hline $\mathbf{4}$ & 50 & 180 & 12 & 82.05 & 13.17 & 25.59 & 3.41 & 5.21 \\
\hline $\mathbf{5}$ & 60 & 180 & 10 & 81.17 & 15.7 & 24.81 & 4.19 & 5.68 \\
\hline $\mathbf{6}$ & 60 & 180 & 10 & 82.96 & 14.53 & 23.76 & 5.24 & 5.63 \\
\hline $\mathbf{7}$ & 50 & 180 & 8 & 70.12 & 19.41 & 19.89 & 10.24 & 3.8 \\
\hline $\mathbf{8}$ & 70 & 180 & 8 & 76.47 & 18.47 & 21.67 & 8.33 & 4.36 \\
\hline $\mathbf{9}$ & 60 & 120 & 8 & 71.39 & 16.88 & 18.52 & 9.48 & 4.76 \\
\hline $\mathbf{1 0}$ & 60 & 180 & 10 & 79.81 & 13.44 & 23.1 & 5.9 & 6.02 \\
\hline $\mathbf{1 1}$ & 50 & 120 & 10 & 81.79 & 14.2 & 22.15 & 5.18 & 5.51 \\
\hline $\mathbf{1 2}$ & 70 & 240 & 10 & 83.31 & 13.52 & 22.07 & 5.93 & 5.04 \\
\hline $\mathbf{1 3}$ & 70 & 120 & 10 & 83.32 & 12.96 & 22.94 & 4.76 & 5.71 \\
\hline $\mathbf{1 4}$ & 60 & 240 & 12 & 85.13 & 12.81 & 26.62 & 3.38 & 6.39 \\
\hline $\mathbf{1 5}$ & 70 & 180 & 12 & 86.34 & 10.52 & 28.24 & 3.76 & 6.32 \\
\hline $\mathbf{1 6}$ & 50 & 240 & 10 & 80.92 & 14.74 & 21.96 & 6.04 & 5.33 \\
\hline $\mathbf{1 7}$ & 60 & 180 & 10 & 81.74 & 13.84 & 24.21 & 5.89 & 5.97 \\
\hline & & & & & & & & \\
\hline
\end{tabular}


Table.2 Solutions for optimal condition

\begin{tabular}{|c|c|c|c|c|c|c|c|c|c|c|}
\hline $\begin{array}{l}\text { Sr. } \\
\text { no. }\end{array}$ & $\begin{array}{l}\text { Drying } \\
\text { temperature } \\
\left({ }^{0} \mathrm{C}\right)\end{array}$ & $\begin{array}{l}\text { Drying } \\
\text { time(min). }\end{array}$ & $\begin{array}{l}\text { Clearance } \\
\text { between pair } \\
\text { of disc }(\mathrm{mm}) \text {. }\end{array}$ & $\begin{array}{l}\text { Decortication } \\
\text { efficiency }(\%) \text {. }\end{array}$ & $\begin{array}{l}\text { Unshelled } \\
\text { nut }(\%) .\end{array}$ & $\begin{array}{l}\text { Whole } \\
\text { kernel } \\
(\%) .\end{array}$ & $\begin{array}{l}\text { Broken } \\
\text { kernel } \\
(\%) .\end{array}$ & $\begin{array}{l}\text { Capacity of } \\
\text { machine } \\
(\mathrm{kg} / \mathrm{h}) \text {. }\end{array}$ & Desirability & \\
\hline 1 & 69.610 & 163.879 & 12.000 & 85.299 & 11.506 & 27.527 & 3.687 & 6.232 & 0.900 & Selected \\
\hline 2 & 69.538 & 163.907 & 12.000 & 85.286 & 11.511 & 27.523 & 3.685 & 6.236 & 0.900 & \\
\hline 3 & 69.582 & 163.445 & 12.000 & 85.294 & 11.508 & 27.519 & 3.686 & 6.235 & 0.900 & \\
\hline 4 & 69.654 & 163.011 & 12.000 & 85.307 & 11.502 & 27.517 & 3.688 & 6.233 & 0.900 & \\
\hline 5 & 69.596 & 164.949 & 12.000 & 85.296 & 11.507 & 27.542 & 3.686 & 6.229 & 0.900 & \\
\hline 6 & 69.455 & 164.412 & 12.000 & 85.271 & 11.517 & 27.525 & 3.682 & 6.239 & 0.900 & \\
\hline 7 & 69.733 & 163.945 & 12.000 & 85.321 & 11.496 & 27.536 & 3.691 & 6.224 & 0.900 & \\
\hline 8 & 69.355 & 164.250 & 12.000 & 85.253 & 11.525 & 27.516 & 3.679 & 6.245 & 0.900 & \\
\hline 9 & 69.286 & 163.432 & 12.000 & 85.240 & 11.530 & 27.499 & 3.677 & 6.253 & 0.900 & \\
\hline 10 & 69.264 & 164.362 & 12.000 & 85.236 & 11.532 & 27.511 & 3.676 & 6.250 & 0.900 & \\
\hline
\end{tabular}

Table.3 Analysis of variance and regression coefficients of the second-order polynomial model for the response variables (in actual units)

\begin{tabular}{|c|c|c|c|c|c|c|c|c|c|c|c|c|}
\hline \multirow[t]{2}{*}{ Sr.no. } & \multirow[t]{2}{*}{ Variables } & \multirow[t]{2}{*}{ Df } & \multicolumn{5}{|c|}{ Estimated coefficients } & \multicolumn{5}{|l|}{ F values } \\
\hline & & & WK & DE & $\mathbf{U N}$ & BK & $\mathbf{C M}$ & WK & DE & $\mathbf{U N}$ & BK & $\mathbf{C M}$ \\
\hline 1 & model & & -7.76292 & $\begin{array}{l}- \\
35.996 \\
6\end{array}$ & 62.23167 & 5.47 & -23.08053 & $36.76^{* *}$ & $33.66 * *$ & $38.97 * *$ & $59.92 * *$ & $17.27 * *$ \\
\hline 2 & $\mathbf{T}$ & 1 & 0.066625 & 0.1820 & -0.075625 & -0.26 & 0.51380 & $5.69 *$ & $9.38 *$ & $6.69 *$ & 1.66 & 2.85 \\
\hline \multirow[t]{3}{*}{3} & $\mathbf{t}$ & 1 & 0.12546 & - & - & - & -3.979 & 0.69 & - & - & - & 4.16 \\
\hline & $\mathbf{T}^{2}$ & 1 & & & & & -4.117 & - & - & - & - & $6.53 *$ \\
\hline & $\mathbf{t}^{2}$ & 1 & 004 & - & - & - & & $10.02 *$ & - & - & - & - \\
\hline 4 & $\mathbf{C}$ & 1 & 1.59688 & 18.745 & -7.25681 & -3.02 & 2.22668 & $\begin{array}{l}130.66^{*} \\
*\end{array}$ & $75.95 * *$ & $101.96 * *$ & $\begin{array}{l}222.47 * \\
*\end{array}$ & $67.47 * *$ \\
\hline 5 & $\mathbf{C}^{2}$ & 1 & - & $\begin{array}{l}- \\
0.8077 \\
8\end{array}$ & 0.28903 & 0.95 & -0.0873 & - & $15.64 *$ & $8.28 *$ & $11.65^{*}$ & $4.70^{*}$ \\
\hline 6 & Lack of fit & 9 & & & & & & $1.47^{\mathrm{NS}}$ & 1.49 & $0.59^{\mathrm{NS}}$ & $0.31^{\mathrm{NS}}$ & $0.96^{\mathrm{NS}}$ \\
\hline 7 & $\mathbf{R}^{2}$ & & 0.9246 & 0.8859 & 0.8999 & 0.9523 & 0.8870 & & & & & \\
\hline 8 & Adj. $\mathbf{R}^{2}$ & & 0.8994 & 0.8596 & 0.8769 & 0.9364 & 0.8357 & & & & & \\
\hline 9 & CV\% & & 3.40 & 2.10 & 5.68 & 9.69 & 6.14 & & & & & \\
\hline
\end{tabular}


Fig.1 Process flow chart for chironji nut decortication

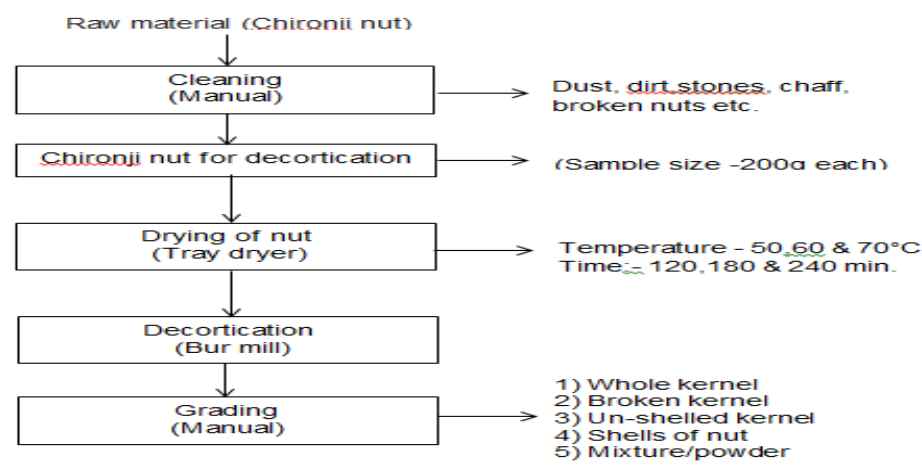

Fig.2 Response surface and contour plots for whole kernel recovery of chironji nut as a function of drying temperature, drying time and clearance between disc. For each plot, the third parameter is fixed at " 0 " level
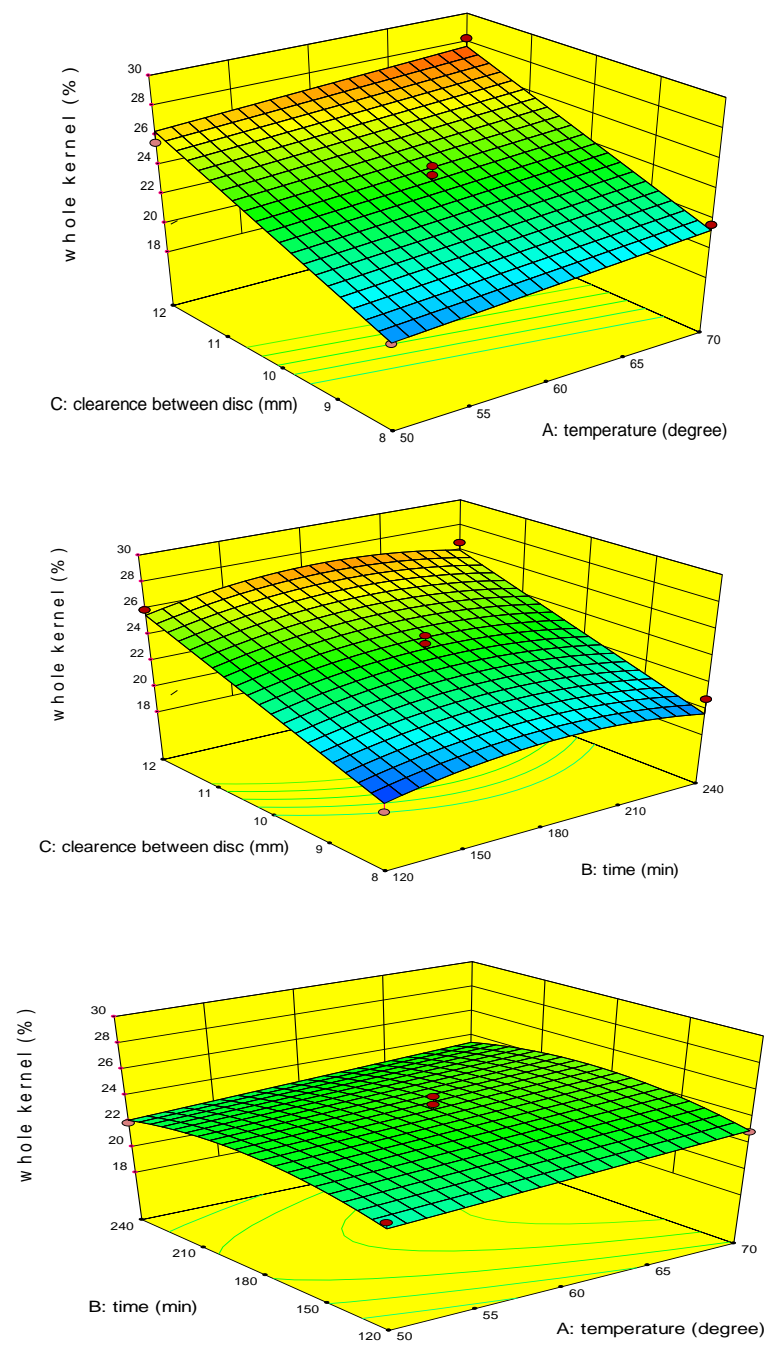
Fig.3 Response surface and contour plots for dehulling efficiency as a function of drying temperature, drying time and clearance between disc. For each plot, the third parameter is fixed at " 0 " level
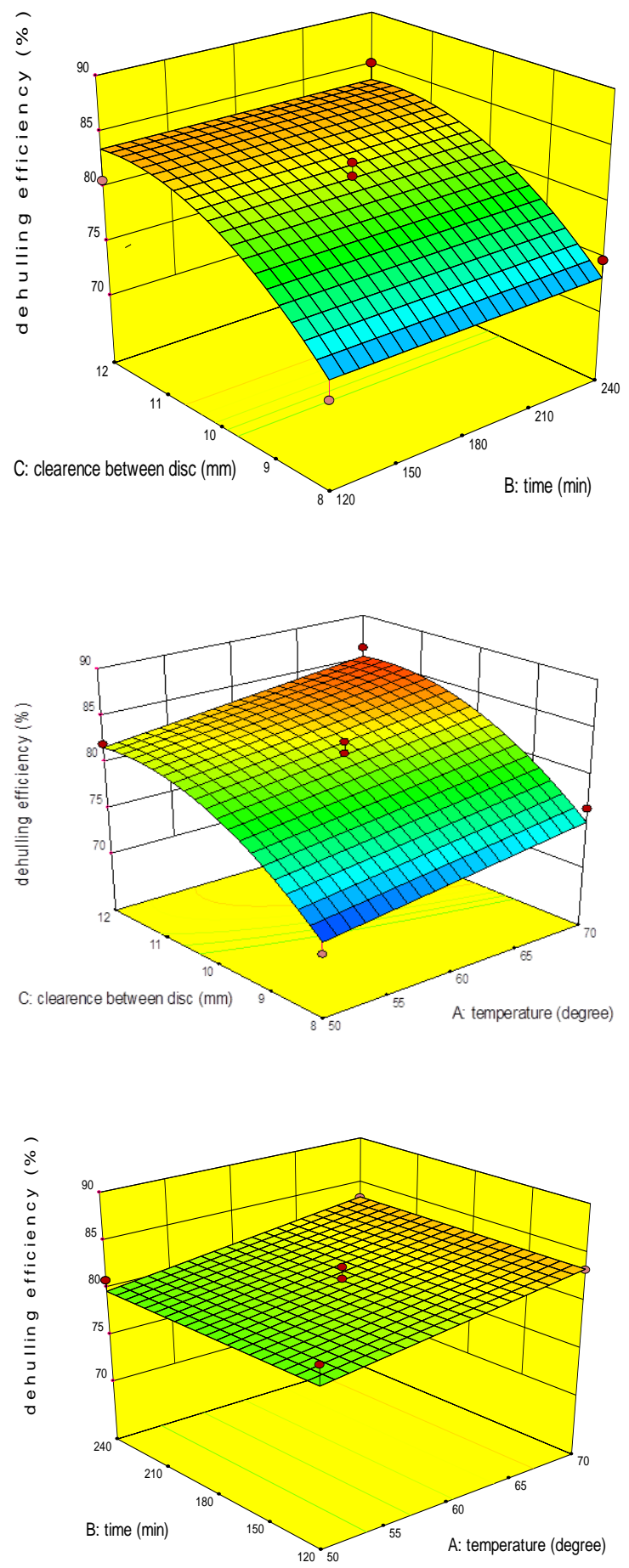
Fig.4 Response surface and contour plots for unshelled nut as a function of drying temperature, drying time and clearance between disc. For each plot, the third parameter is fixed at " 0 " level
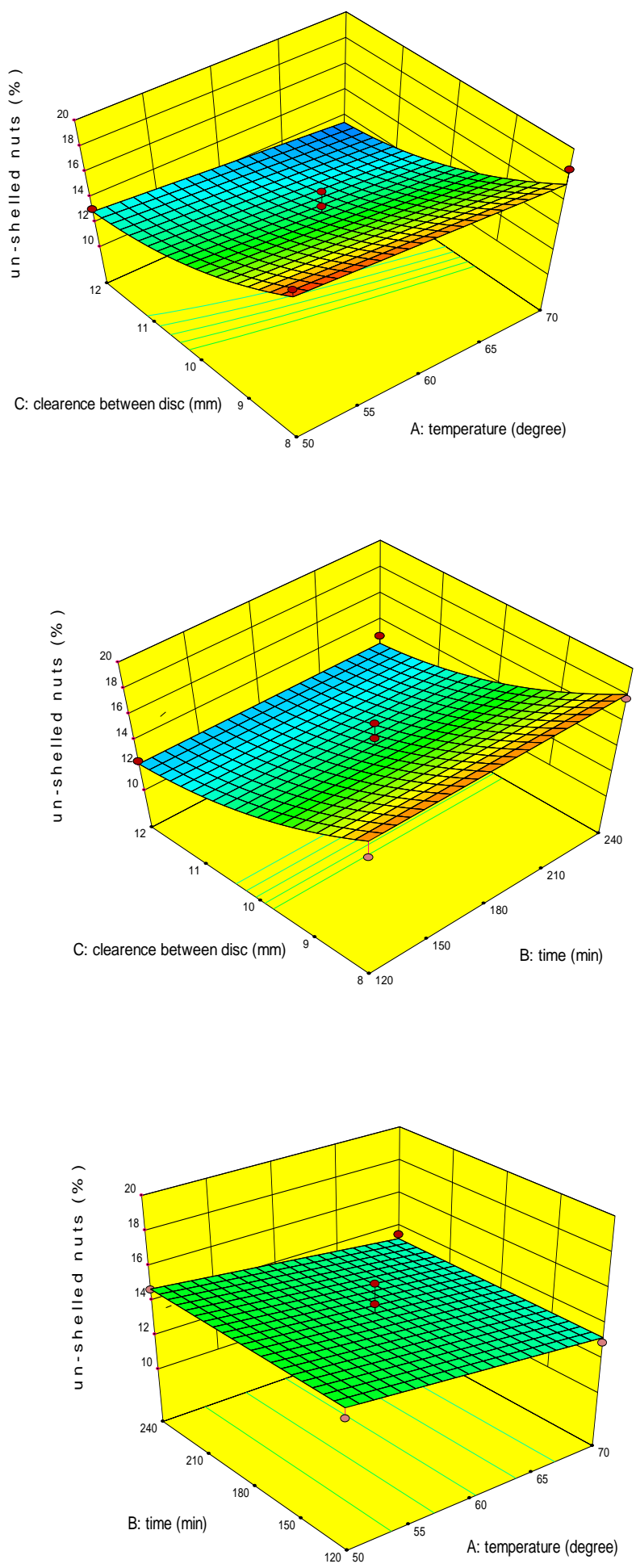
Fig.5 Response surface and contour plots for broken kernel as a function of drying temperature, drying time and clearance between disc. For each plot, the third parameter is fixed at " 0 " level
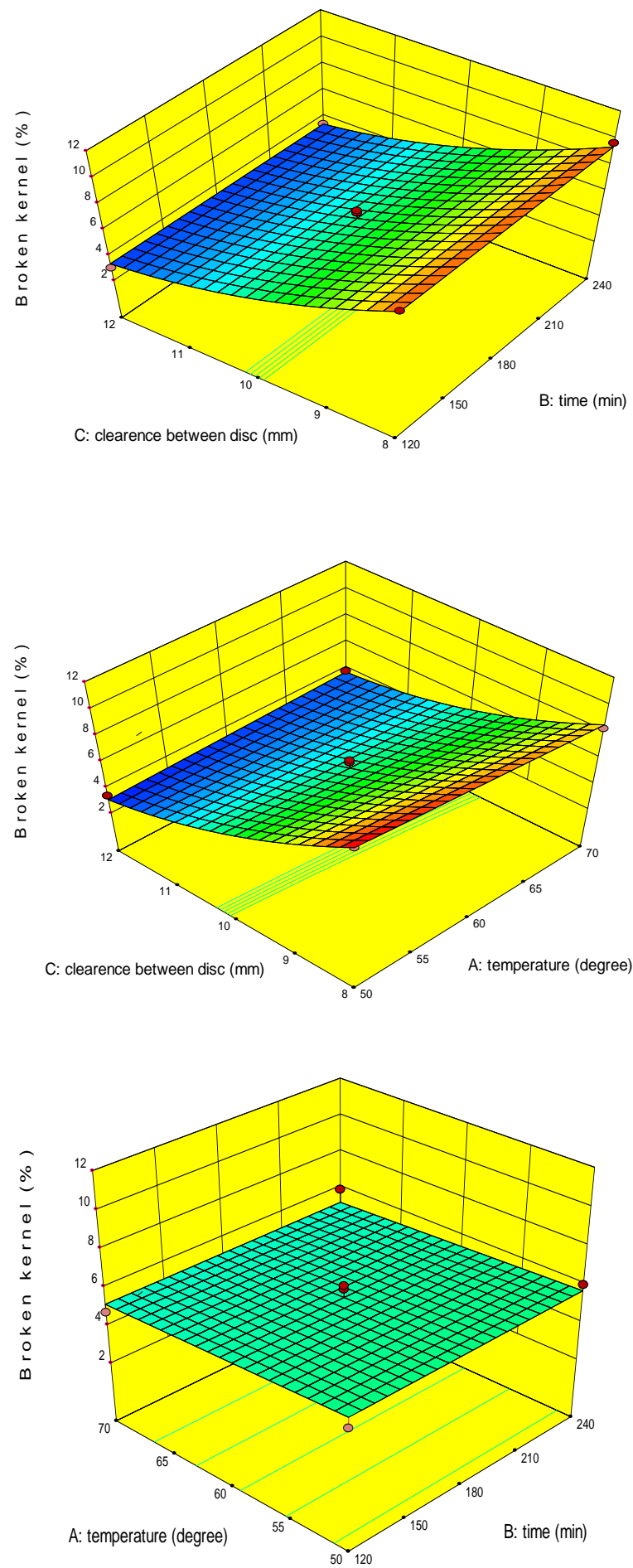
Fig.6 Response surface and contour plots for capacity of machine as a function of drying temperature, drying time and clearance between disc. For each plot, the third parameter is fixed at " 0 " level
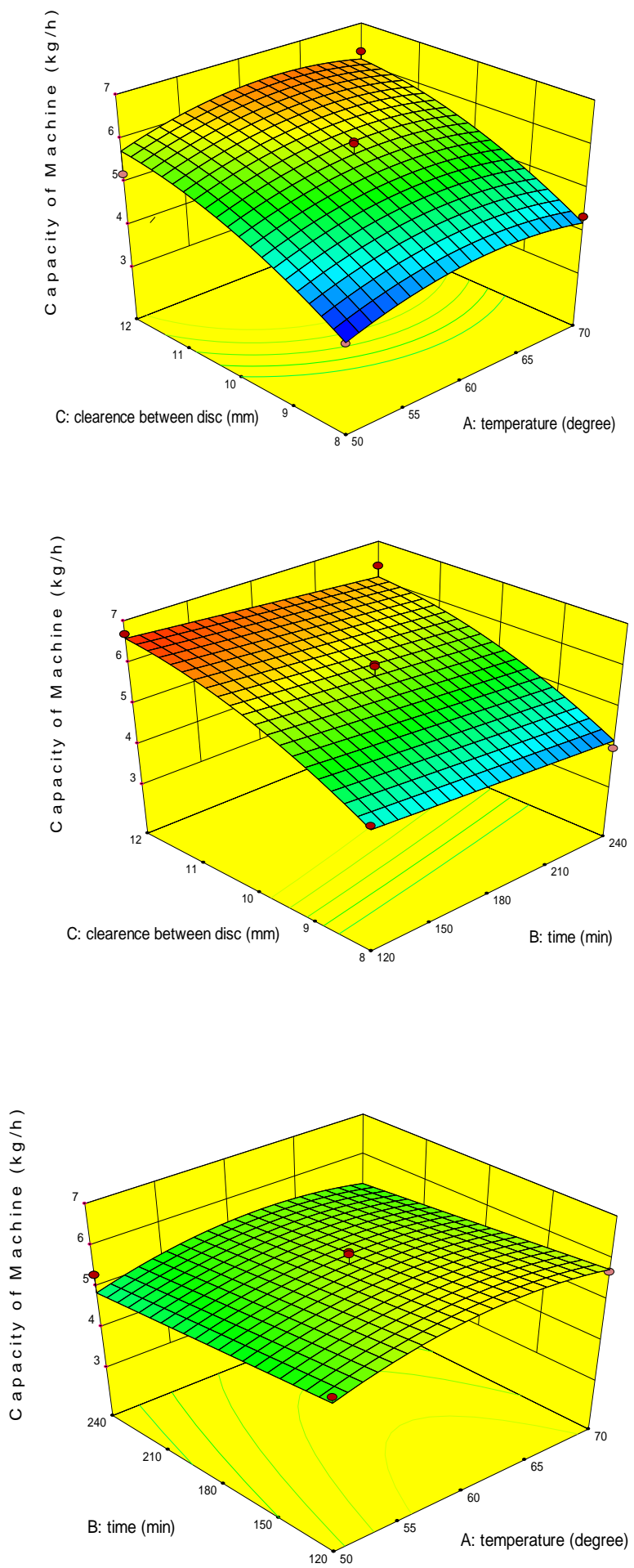
Fig.7 Optimization of independent parameters
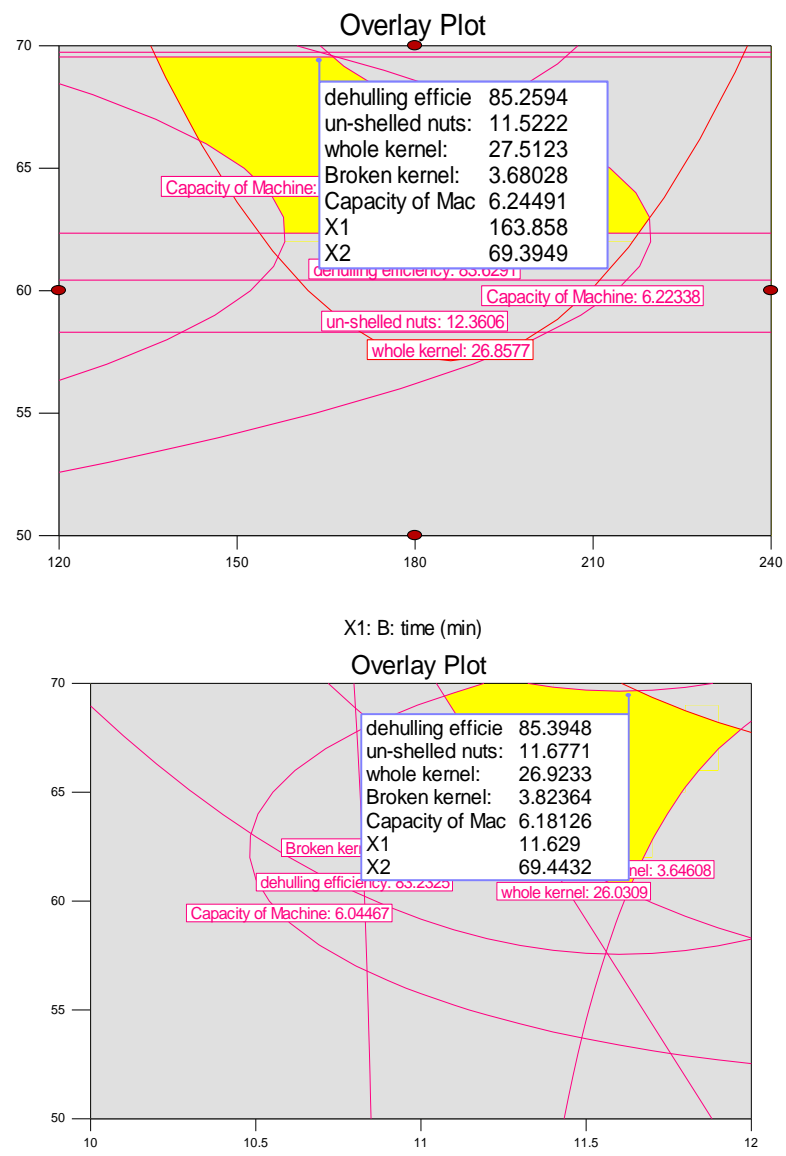

X1: C: clearence between disc (mm)

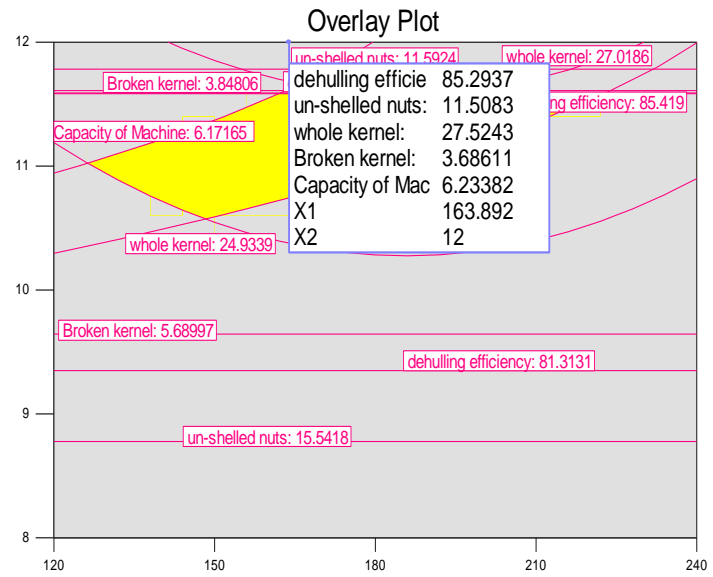

X1: B: time (min)

In conclusion the superimposed contours showed the optimized result, where the independent parameters were drying temperature of $69.610{ }^{\circ} \mathrm{C}$, drying time 163.87 min and clearance between disc $12.00 \mathrm{~mm}$ thus the responses showing predicted value as $85.299 \%$ for decorticating efficiency, $27.527 \%$ for whole kernel recovery, $11.506 \%$ for unshelled nut, $3.687 \%$ for broken kernel and $6.232 \mathrm{Kg} / \mathrm{h}$ for capacity of machine were 
obtained. The calculated $\mathrm{F}$ value for lack of fit for all responses was found to be less than tabular values, which indicates that the regression equation obtained though RSM are in close agreement with the experimental values.

The investigation proves that the slight change in the clearance between the pair of discs of burr mill (machine) along with drying temperature and drying time helped in saving labour, saving cost of operation, reduction in drudgery and time and improving quality of kernel. Thus the burr mill could be used as chironji nut decorticator.

\section{List of Symbols and Abbreviations}

\begin{tabular}{|c|c|}
\hline $\mathrm{Y}_{\mathrm{k}}$ & $\begin{array}{l}\text { Predicted value of the responses } \\
\text { from the developed models }\end{array}$ \\
\hline $\mathrm{T}$ & Drying temperature \\
\hline $\mathrm{t}$ & Drying time \\
\hline $\mathrm{C}$ & Clearance between disc \\
\hline WK & Whole kernel \\
\hline $\mathrm{DE}$ & De-hulling efficiency \\
\hline UN & Unshelled nut \\
\hline BK & Broken kernel \\
\hline $\mathrm{CM}$ & Capacity of machine \\
\hline RSM & Response surface methodology \\
\hline $\begin{array}{l}\mathrm{x} 1, \quad \mathrm{x} 2, \\
\text { and } \mathrm{x} 3\end{array}$ & $\begin{array}{l}\text { Coded values of the independent } \\
\text { variables } X 1, X 2 \text {, and } X 3\end{array}$ \\
\hline
\end{tabular}

References

Bashiri, I.M., Zubairu, M. and Olorunaye, E. S. (2013). Design and construction of a machine for decorticating bambara nut. $\mathrm{J}$. Rind 11(2): 355-360.

Chandhar, S.K. and Sharma, M.C. (1997). Trends in fruit production in Buchanania lazan trees. Vaniki Sandesh 21, 1-3

Davies, R. and Mohammed, U.S. (2013). Engineering properties of bitter kola nuts and shell as potentials for development processing machines. IJSRES.1(11):337343.

Gabadam, E.K., Anthony, S. and Asiam, E.K. (2009). The determination of some design parameters for palm nut crackers. European J. of scientific research, 38(2): 315-325.

Jose Dalton Cruz Pessoa and Johannes Van Leeuwen (2006). Development of a shelling method to recover whole kernels of the cutia nut (Couepia edulis). Rev. Bras. Frutic., Jaboticabal - SP- 28(2): 236239

Kumar Jitendra; Prabhakar, P.K., Srivastav, P.P. and Bhowmick, P.K. (2014). Physical characterization of chironji (Buchanania lanzan) nut and kernels. Food Sci. Res. J., 5(2): 148-153

Mangaraj, S., and Kapur, T. (2005). Milling studies of pulses using different pre milling treatment and abrasive roller assembly. Agricultural Engineering Today, 29(5-6), 64-70.

Myers, R.H. and Montgomery, D.C. (2002). Response Surface Methodology. Process and Product Optimization using Designed Experiments. Wiley, New York

Rai, Y.C. (1982), Buchanania lazan, Spreng. studies on methods of propagation and estimation of fruit yield. Indian Forester 108, $501-511$.

Sahay, K. M., and Bisht, B. S. (1988). Development of a small abrasive cylindrical mill for milling pulses International Journal of Food Science \& Technology, 23(1), 17-22.

\section{How to cite this article:}

Dange, M.M., P.S. Champawat, P.H. Bakane, S.D. Deshmukh, S.K. Jain and Borkar, P.A. 2019. Process Parameters for Chironji Nut (Buchanania lanzan.) Decortication. Int.J.Curr.Microbiol.App.Sci. 8(01): 1848-1862. doi: https://doi.org/10.20546/ijcmas.2019.801.195 